\section{Community Agency and Islamic Education in Contemporary Zanzibar}

\section{CAITLYN BOLTON}

Western liberal political philosophy, which undergirds the conception of the modern nation-state as theorized by European philosophers of liberalism from centuries past, is primarily concerned with the dynamics of rights and responsibilities between the individual and state institutions. In defining these dynamics, some philosophers held an assumption of human nature as inherently inclined toward selfish ends, and as such they thoroughly questioned to what extent the state could intervene in the life of individuals in order to curb destructive and antisocial behavior. Others idealized the "state of nature" as peaceful, but, writing in the era of absolutist monarchs, they were primarily concerned with limiting the reach of sovereign power. Yet with whichever approach, "community" is not a viable actor in such theories, concerned as they are with arbitrating between the "freedom" of the individual and the coercive power of state institutions. Indeed, the very concept of community, especially communities of "minorities," is antithetical to the modern nation-state, as it implies allegiance to something other than the nation itself (Mahmood, Religious Difference 51-53).

Further, "harm" in this context means that which the state can redress through its judiciary, making it difficult to conceive of and address collective forms of oppression (Schwartzman), as they permeate daily life in microaggressions and regular expressions of prejudice, only some of which qualify for legal punishment. "Action" within this theoretical framework-the only recourse to individuals who have been harmed-means demanding that the state act, either through legislative change or judicial punishment. Yet while institutional and legal change affords important protections, injustice is incredibly resilient in the face of legal change. It adapts to and mutates within new structural limitations, finding legal loopholes and new euphemisms within which to operate. ${ }^{1}$

Examining communal social action within a part of the world not fully steeped within such ideologies offers insights into other forms of agency, forms that function within different paradigms of social life. Such examples of communal agency are "constructive" in that they focus on building new communal structures, structures

1 Paul Lample describes this with regards to race in the United States, with the official legal abolishment of slavery followed by Jim Crow laws and sharecropping, and with civil rights accompanied by other forms of institutionalized racism, such as mass incarceration (9). See also Alexander. 
that attend to the immediate concerns of local reality while striving to inspire others at a broader level. The examples that follow, as with those from other Islamic societies, do not conform to normative liberal conceptions that understand agency "as a synonym for resistance to relations of domination," rather than simply "a capacity for action" (Mahmood, Politics of Piety 18). This normative liberal conception of agency frames much of both popular and scholarly thought that seeks out examples of and romanticizes "resistance" (Abu-Lughod 41). While the kinds of agency described here operate within contexts of oppression that they seek to change, such agency is not principally about "resisting" authoritative structures and institutions, but instead creating new structures and patterns of community life that mirror the values they wish to see enacted, in this case values rooted within Islam.

Here I share, from my doctoral fieldwork on the East African islands of Zanzibar, the experiences of two friends and the communities within which they work as they seek to change their own and others' lives within the context of various forms of oppression. I share from Ustadh Juma, ${ }^{2}$ a senior teacher at the largest Islamic school in Zanzibar, Madrasat Al-Núr, as he employs an Islamic education directed at countering the effects of Zanzibar's increased embeddedness in global capitalism since the end of Tanzania's socialist project in 1985, particularly the

$2 \quad$ All names are pseudonyms. resulting rise in individualism and class stratification. In his classes, he emphasizes prosocial behavior and spiritual virtues central to community life, commenting directly on capitalist thought and its effects. More broadly, he contests the wider development ideology that posits Zanzibar as always behind, always the recipient of development knowledge but never the generator, by emphasizing to his students the ways in which they and Zanzibar are more "advanced" than the "advanced" nations - particularly in community cooperation and trust in God.

I also share from Rehema, a domestic worker who helped start a women's Islamic study circle in order to collectively advance the participants' own spiritual and material progress within the context of what Rehema describes as mfumo dume, literally the "male system" or patriarchy. Like Madrasat A1Núr, the women's Islamic study circle seeks to engender community bonds among its participants, countering prevailing forces of individualism. This can be seen not only in the name of their group, Madrasat Jihád Al-NafsSchool for Battling the Self_-but also the ways in which it serves as a vector for social, spiritual, and material support, particularly during times of hardship. It is also an opportunity for Rehema-who only completed a few years of formal education - and others to advance their education, as well as a space for women to occupy positions of Islamic leadership.

While offering examples of communal forms of agency, Ustadh Juma's 
and Rehema's experiences underscore a key challenge inherent to communal action, namely achieving a collective vision or conceptual framework. Here, action is undertaken within the framework of Islam, what they often refer to as a "framework/system of life" ( $m f u$ mo wa maisha) — but whose Islam? In the absence of a universally agreed-upon Islamic authoritative body to guide interpretation, tensions arise as to the correct understanding of Islam and how that manifests in community life. For Ustadh Juma and his Madrasat Al-Núr, this plays out in the increased influence of Saudi Salafism, as a few teachers deride communal practices such as the school's celebration of the Prophet's birthday and engage in Salafi call-out culture that publicly shames others for what they deem illegitimate Islamic practice. For Rehema and her study circle, such tensions play out as, while carving new spaces for female Islamic leadership and advanced learning, they struggle to achieve consensus on other issues such as the permissibility of women attending communal prayers at the mosque.

\section{USTADH JUMA: IsLAMIC EDUCATION FOR SPIRITUAL Progress}

"A seller who prices his rice three times higher during scarcity is following the ideas of capitalism (fikra za kibepari), where each market increases in order to bring a profit," explained Ustadh Juma in his virtues class in the largest Islamic school (madrasa) in Zanzibar. In such a case, he continued, only the wealthy can afford to eat, while a virtuous seller would lower the price for the poor. Ustadh Juma regularly speaks about capitalism in his classes, in between reading from the Arabic textbooks imported from Saudi Arabia. When I asked him why he speaks about capitalism so much in class, he responded: "Because in capitalism, your mind is only focused on economic benefit . . . yet economic benefit [alone] does not take care of people or anything else. . . This is not a good thing in Islam or any society because what is its result? It divides people into classes. . . There are times when you must put people before profit."

Ustadh Juma and other Islamic educators in Zanzibar see their work as a vital corrective to the rising individualism and class stratification associated with increased embeddedness in capitalist processes, especially since the end of Tanzanian socialism in 1985 and the country's opening to global capitalist development, investment, and structural adjustment loans. The 1980s and '90s saw a rapid expansion of development in infrastructure and new economic sectors, including the extension of electricity and paved roads throughout the island, the growth of tourism, and the introduction of seaweed farming for women as an export commodity. Economic and social life has shifted drastically, prompting what many articulate through the language of "moral decline." Youth exposure to the wealthier lifestyles of tourists, as well as access to cash, invites new consumer patterns including 
conspicuous consumption of clothing, cell phones, and other expensive items. Conspicuous consumption is read as highly individualistic and antisocial in a society whose social institutions such as weddings and funerals are characterized by high reciprocity, and where any economic windfall is expected to be shared among one's networksZanzibaris often purchase items like flour and kerosene in small amounts daily rather than in bulk, as stockpiling brings the obligation to share (Winther 151). That capitalist acquisition is inimical to this expectation can be seen in the fact that the word for "capitalism" in Swahili (ubepari) is linked to the word for "hoarder" (bepari).

Ustadh Juma narrated this decline through the language of unity: "Unity has decreased a lot ... and people are not visiting each other as much." It used to be that everyone had nearly the same income, he continued, but now there are significant differences and people are living behind fences and gates - and if he wants to visit with them, he must make an appointment. Ustadh Juma regularly commented on the opening of the first gated community in Zanzibar, called Fumba Town, which would have its own community institutions including a school, mosque, and shopping center. This would vacate the wealthy from sites where they would otherwise interact with the poor, lessening opportunities for generosity and redistribution of wealth during community events such as weddings and funerals. "All of those with means will leave," he explained, "and the poor will not have any helper."

Islamic education is seen as a vital corrective to these trends because it has the power to quiet the self, to lessen greed in preference for community welfare, and to inculcate spiritual qualities in children and youth that result in the wellbeing of all. Secular studies, Ustadh Juma's colleague Salmin explained, are primarily for the individual to advance personally and economically by ensuring a good income. But Islamic education primarily benefits society, Salmin continued, because it "builds a person individually, his values so that he is truthful, trustworthy, and loves to do work" that then translates into broader society so that "we help each other, respect each other, and sit well together as a community." Many Zanzibaris see this centrality of community, as enhanced by Islamic piety, as one of the most laudable features of their society. Given that dominant development approaches assume a linear movement of knowledge from the Global North to the South, valuing "local knowledge" largely in isolated techniques rather than broader ways of knowing that might also be relevant to the North, I asked Ustadh Juma how he felt Zanzibar was more "advanced" and what "developed countries" can learn from it. "Community cooperation," he replied.

Further, while highlighting the advances of Europe and the United States that he hoped Zanzibaris will emulate, such as a spirit of volunteerism, he often would encourage his students to value their own strengths. For 
example, in one class he paused to ask me how to say a word in English, and then used it only in English throughout his lecture: "stress." In the United States and Europe, he explained, they have more wealth but they also have so much stress that they have to go to psychologists. In Zanzibar and other Islamic countries, he explained, people are poor but they rely upon God and therefore become calm as reliance on God removes stress.

Ustadh Juma used Islamic education not only as a tool to counter rising individualism and class stratification, but also to bolster his students' sense of self-worth within a global structure that, as they are well aware, casts them as "third world" or "developing" and therefore not a source of globally relevant knowledge. Ustadh Juma effectively flipped that formulation by introducing a spiritual measure alongside the dominant material measure - the United States and Europe may be more successful materially, alongside those Zanzibaris who have benefitted from capitalist development, but that is not the sole index of inherent worth. Zanzibaris, despite largely being materially poor, have much that the "developed" world can learn from: their reliance on and trust in God, and the centrality of community as built through spiritual education. This manifested in the communal activities surrounding the school, including the mawlid celebrations of the Prophet's birthday or the iftar dinners served after fasting during Ramadan, where some of the wealthiest Zanzibari businessmen can be seen serving food to the children and other attendees.

Yet not all of the teachers at the school hold the same vision, causing tension in the breakroom. This was principally a result of the increased influence of Saudi Salafism and its denigration of popular Islamic communal practices and values - whether in publicly denouncing communal spaces of Sufi worship, or in the lack of respect afforded to elders and their knowledge or authority. Public shaming of elders, alongside regular Salafi denigration of popular communal practices, runs counter to the kinds of prosocial virtues taught in Ustadh Juma's classes-for example, when he tells his students not to admonish others for incorrect practice as the "method of the Prophet was that of conversation," not accusation.

\section{Rehema: Battling the Self for Collective WellBeing}

Packed tightly in the dala dala minibus careening around the traffic circle, I protested that Rehema had paid my fare before I even had the chance to pull out my own change. She smiled and said not to worry, that she would get thawabu, or extra blessings, for it. To return the favor, I learned to be quicker about having coins in hand during our subsequent trips to her women's $m a$ drasa. Rehema was a domestic worker from mainland Tanzania who has lived and worked in Zanzibar most of her adult life, and we attended the madra$s a$ with another friend who lived in the guesthouse where Rehema worked. 
She tapped the metal roof with coins to indicate our stop to the driver, and we squeezed out of the minibus onto the side of the road. Passing through a local market selling house and kitchen wares, we emerged into a residential area crisscrossed by dirt paths between concrete walls topped by corrugated metal roofs. As we entered the meeting room, Rehema drew her black niqáb face veil over the top of her head to reveal her smiling face, and we were greeted by similarly dressed and smiling women as we found places on the carpeted floor to sit and talk while waiting for class to begin.

Like Madrasat Al-Núr, this adult women's madrasa is focused on countering the forces of individualism through the creation of a community space within which Islamic education can inspire individual and collective pious behavior. This can be seen in the name that they chose for their groupMadrasat Jihád An-Nafs, meaning School for Battling the Self. "Jihad is what trains us, it is fighting with the self . . . it makes me progress developmentally for the afterlife," Rehema explained. Jihad is not something for terrorists (magaidi), she continued, because "we cannot fight because of Islam, people are mistaken. Now we do not fight wars, we fight to study. We study so that we understand, we must explain that now we are fighting to become self-liberated." Jihád an-nafs means to "remove a person from a state of ignorance," she said, to battle with the self until "we are sated with the real food, this book."
This communal focus can be seen in both the behavioral patterns and content of the madrasa space. For example, on days that they do not study, they gather simply to read the Qur'an together. When I asked why they come together only to read individually, their teacher Zahra explained that if they were at home, they would not be able to read given their domestic responsibilities; further, "If we sit together, we can help each other understand." The content of the classes bolstered this communal focus by regularly emphasizing that personal piety is demonstrated through good works to others, as praying and fasting alone are not sufficient - all must greet their neighbors and solve their problems together, as one cannot say, "I myself am fine." In one class, a teacher enumerated the "rights" (haki) that Muslims have from one another: to be greeted with "peace be upon you," to be told "God bless you" if one sneezes, to be taken care of if sick, and to have the funeral attended if one dies. "Rights" in this context are explained not as individual rights protected by state institutions, but as the responsibilities of care that Muslims are obligated to afford to one another.

This kind of social and moral communal imbrication is evidence of what Haj describes in Islam as "a view of the relationship between the individual, the community, and the state that differs from the European liberal humanist tradition" (28), where individual worship ( 'ibáda) and practice "assumes an individual belonging within the community" (29) and indeed that a "Muslim 
cannot attain these virtues except as a member of a community" (42). One cannot operate as "an independent, rationally detached individual" given that all are "held accountable for each other's moral state of being" (41). I felt this tension between an American understanding of individual rights and an Islamic communal moral obligation one day when I arrived at the madrasa and was eagerly called over by Awatif, a woman with whom I had had friendly conversations during previous weeks. As usual when entering Islamic spaces, I had wrapped a scarf around my head-yet that day I tied it such that part of one ear could be seen, the final flap pinned above my ear rather than tucked under my chin. As I sat down next to her, Awatif promptly tucked my scarf under my chin. At first I resented what felt like an intrusion on personal space and a violation of religious freedom given that, not being a Muslim, I wore it only out of respect. Immediately to my mind came a Qur'anic verse- "let there be no compulsion in religion" (2:256) - that was frequently invoked in my previous workplace, a U.S. Islamic organization, to show that Islam promotes an American-style freedom of religion. Yet whenever I mentioned this verse to Zanzibari Muslims, I did not get the knowing nods that I got in the United States, as it was not as commonly cited and referred to. In the United States, rights and freedoms are often articulated in the negative (as freedom from), implying that the individual should be able to pursue what they like without encroachment by others on their speech, religious practice, and other behavior. Yet in this context, "rights" (haki) entailed the right to receive care from other community members, care which also manifested as moral correction.

Rehema saw this space as especially vital given what she describes as "mfumo dume," the male system or patriarchy. The kind of care that the women give each other is not only spiritual, but also social, including visiting each other when ill and consulting together on problems, and material, as they pool together money when someone is in need, and Rehema herself has found domestic work for tens of women who could not have found it otherwise. They can therefore achieve a "self-reliance" where the "self" is in the collective, referring to the women of the group as a whole (Ott). With her madrasa, she has found an avenue to advance her own education. This kind of advanced Islamic education for women provides them room in Islamic leadership, which is a male-dominated field. And this space allows for women to gain their own understanding of Islam and the Qur'an that allows them to question their husbands' Islamic justifications for demands such as, Rehema describes, that their wives should not leave the home.

At the same time, the kinds of social action demonstrated in Rehema's group are constrained by tensions at the level of conceptual framework, especially as related to correct Islamic interpretation. This manifests in moments of disagreement in class, for 
example, in one study class when the women read from their textbook that only men must attend Friday prayers at the mosque. Some agreed, saying that women's main role on Friday is to close their shops to encourage neighborhood men to attend mosque. Rehema interjected that she sometimes attends Friday prayers at the mosque. Another replied that it is not forbidden, but that "the man is the leader even if he is a child" and so she should first send the men in her home. This challenge also manifested in their efforts to expand their circle; for example, when they traveled to a rural village to open another women's madrasa, they were rebuffed by many in the village as "terrorists" (magaidi) because their long black over-dresses and niqáb face coverings were not common outside of town and signaled a new conservatism. Lastly, while providing spaces for women's Islamic leadership, the head teacher Zahra was clear that women have limits and cannot be leaders more broadly.

\section{Community Agency AND Social Change}

Ustadh Juma, Rehema, and the groups within which they work see themselves as operating within contexts defined by powerful oppressive forces. Ustadh Juma and colleagues see their teaching as countering the forces of rising individualism and class stratification. They aim to cultivate spiritual virtues that result in prosocial behavior, strengthening the bonds of community that then become spaces within which social change occurs, including the pious redistribution of wealth. Ustadh Juma also seeks to inculcate in his students a sense of individual and collective selfworth, emphasizing that Zanzibar has many strengths that other global communities can learn from. While he never explicitly mentioned race, we could see his work as operating within contexts of racism: a global development ideology that sees valuable knowledge as primarily flowing from North to South, and Saudi Salafi proselytism that paints Islam in Africa as muddied by polytheism, whether through the predominance of Sufi practices or popular recourse to magic. For Rehema and the women in her madrasa, they also see their communal space as countering the forces of individualism, as they "battle the self" to collectively work for their spiritual, social, and material wellbeing. This helps them each to weather life's hardships as vectored through class and gender inequalities, while opening up Islamic educational opportunities and knowledge that would otherwise be unavailable to them. Such communal forms of agency are constructive in that they create new structures and patterns of behavior within pockets of Zanzibari society, seeking to address forms of oppression through the creation of new spaces modeled on alternative foundations.

When Ustadh Juma said that "developed" or "advanced" nations could learn community cooperation from Zanzibar, he was responding to the ideologies predominant in the 
United States and Europe, which he experienced through globalized economic and political forces acting upon his tiny island perched on the edges of Africa and the Indian Ocean. (He could not see the long traditions of communal agency among oppressed groups in those regions, some of which are described in this collection.) Examining the features of communal forms of agency in Zanzibar remains relevant more broadly given that the dominant globalized economic and political forces acting upon Zanzibar also act upon those of us in the regions in which they were first articulated. It gives a glimpse of a part of the world where community is a central protagonist in social life, despite the globalized forces that increasingly undermine it. Community's primary role can be seen in patterns of interdependence and the moral responsibility to redistribute one's wealth, including the belief that if one does not share an economic windfall, then they will become physically sick as a result of others' jealousy.

This centrality of community can also be seen in how the language of "rights" (haki) was marshalled in Rehema's madrasa to mean communal rights of care - that one has the right to be told "God bless you" when having sneezed and the right to be cared for when sick. This definition is significant given the highly individualistic framework for understanding rights in the Global North and international institutions. The Universal Declaration of Human Rights, for example, does not address community or minority group rights, making it difficult for groups to use it to address collective injustice. For example, after the Declaration was issued in 1948, the National Association for the Advancement of Colored People tried to make a case for racial equality on its basis, but Eleanor Roosevelt rebuffed it, declaring that the "minority question [does] not exist on the American continent" (Anderson). This lack of protection for community rights prompted the United Nations to pass a Declaration on the Rights of Indigenous Peoples in 2007, which asserts indigenous groups' rights to their own governance and to protect their cultures and religions. Yet its force is limited in being not legally binding, limiting redress to be pursued through national legal frameworks. When rights are legally understood as an attribute of individuals, collective forms of oppression are rendered invisible to liberal state institutions.

The examples of Madrasat Al-Núr and Madrasat Jihád Al-Nafs show responses to collective forms of oppression that are vectored through the agency of communities as guided by Islamic commitments. The impulse to label or glorify such activities as "resistance" to oppressive forces, such as capitalism or patriarchy, is rooted within a Western liberal conception of agency. Scholars of Islamic revivalism have regularly questioned the applicability of the resistance paradigm for analyzing such movements, where agency is not enacted against a structure or institution but rather channeled by it (Mahmood, Politics of Piety 18). 
Yet, what such scholarship does not address in these contexts is the centrality of community as a protagonist of social action between the individual and the state - an actor which is at best ignored or at worst undermined by liberal political philosophies. Centering communal action introduces a form of agency hitherto illegible in such perspectives, a form of agency in response to oppression that is not centered on the individual demanding that institutions act, but that constructs new patterns of behavior on alternative foundations.

Yet, as demonstrated above, a key challenge facing communal social action is that of constructing a shared conceptual framework for that action, a challenge that manifests in Zanzibar in tensions regarding correct Islamic interpretation. In the absence of a universally agreed-upon Islamic interpretive authority, multiple authorities vie for prominence-whether locally at the level of preachers and teachers, or internationally, as with the Saudi Arabian religious elite's attempt to define Islamic orthodoxy through educational scholarships and missionary ventures. Should knowledge generation be a collective process, or one centered on a hierarchical exchange from an individual knower to the group? Are communal Sufi devotional practices permissible, or condemned as polytheistic innovations that muddy the purity of original Islamic practice? Communal action is constrained insofar as such questions remain unanswered.

\section{Works CITED}

Abu-Lughod, Lila. "The Romance of Resistance: Tracing Transformations of Power through Bedouin Women." American Ethnologist, vol. 17, no. 1, 1990, pp. 41-55.

Alexander, Michelle. The New Jim

Crow: Mass Incarceration in the Age of Colorblindness. New Press, 2010.

Anderson, Carol. Eyes off the Prize: The United Nations and the African American Struggle for Human Rights, 1944-1955. Cambridge UP, 2003.

Haj, Samira. Reconfiguring Islamic Tradition: Reform, Rationality, and Modernity. Stanford UP, 2009.

Lample, Paul. Revelation \& Social Reality: Learning to Translate What Is Written into Reality. Palabra Publications, 2009.

Mahmood, Saba. Politics of Piety: The Islamic Revival and the Feminist Subject. Princeton UP, 2011.

_—_ Religious Difference in a Secular Age: A Minority Report. Princeton UP, 2016.

Ott, Jessica. Women's Rights in Repetition: Nation Building, Solidarity, and Islam in Zanzibar. 2020. Michigan State U, PhD dissertation.

The Qur'an: Text, Translation and Commentary by Abdullah Yusuf Ali. Tahrike Tarsile Qur'an, Inc. 2001. 